\title{
Leukocyte Valine Dehydrogenase Activity in Friedreich's Ataxia
}

\author{
A. BARBEAU, T. CLOUTIER, M. CHARBONNEAU
}

SUMMARY: We studied the activity of valine dehydrogenase (VDH) in leukocytes of 14 Friedreich's ataxia patients and of 14 normal control subjects. There was a significant $26 \%$ mean decrease in enzyme activity in the patients, a finding which could be responsible for the chronic accumulation of some $\alpha$-keto acids with toxic metabolic consequences in that disease. However the deficiency was not present in all patients with the typical symptoms, nor was its magnitude sufficient to be considered the primary genetic defect in Friedreich's Ataxia.

RÉSUMÉ: Nous avons étudié l'activité de la valine déshydrogénase (VDH) dans les globules blancs de 14 patients souffrant d'ataxie de Friedreich et de 14 sujets témoins normaux neurologiquement. Nous avons noté une diminution significative de l'ordre de $26 \%$ dans l'activité enzymatique $V D H$ des patients. Ce degré d'inhibition pourrait suffire à favoriser l'accumulation chronique de certains acides alphacétoniques, avec des conséquences métaboliques dans cette maladie. Cependant la déficience en activité VDH ne fut pas notée chez tous les patients présentant les symptômes typiques de la maladie et l'amplitude de cette déficience n'est pas suffisante pour être considérée comme le défaut génétique primaire de l'ataxie de Friedreich.

Department of Neurobiology, Clinical Research Institute of Montreal.

Reprint requests for the complete supplement on Friedreich's A taxia (Phase Three, Part Two) to: Prof. André Barbeau, Clinical Research Institute of Montreal, 110 Pine Avenue West, Montreal, Quebec, Canada, H2W IR 7 .

\section{INTRODUCTION}

Previous studies from our group and others have indicated that the pyruvate dehydrogenase complex $\left(\mathrm{PDH}_{\mathrm{C}}\right)$ was partially deficient in its activity in some patients with Friedreich's Ataxia (for review see Barbeau, 1980). Further investigations revealed similar findings for the activity of alpha-keto glutaric dehydrogenase and oxoglutarate dehydrogenase (Blass et al, 1976). The third component of the complex, lipoamide dehydrogenase (LAD), is one of the common links between the two enzyme complexes. That enzyme has been shown to be deficient in plasma (Barbeau et al, 1976; Livingstone et al, 1980) and possibly to exhibit abnormal kinetics (Kark et al, 1979). However the changes observed were not present in all typical cases of Friedreich's Ataxia, nor were they of sufficient magnitude to be thought primary as they were not present in fibroblasts (Melançon et al, 1978). Moreover we were impressed in our own laboratory by the fact that day to day variations in enzyme activity of these complexes appeared to be markedly influenced by diet, particularly in glucides, a finding not compatible with a basic genetic defect.

For these reasons we searched for another enzyme complex that would embody the same LAD component, but would not be influenced by variations in glucose intake. If a deficiency were again found in the activity of this new enzyme in Friedreich's Ataxia, that observation would strengthen the evidence in favour of the importance of the multienzyme complexes in the pathophysiology of Friedreich's Ataxia. Such an enzyme complex does indeed exist: the dehydrogenase enzyme involved in the oxidative decarboxylation of the branched-chain amino acids: valine, isoleucine and leucine (Johnson and Connelly, 1972), the same enzyme complex is implicated in Maple Syrup Urine Disease (Menkes et al, 1954; Westall et al, 1957). As a control to PDH and $\alpha \mathrm{KGDH}$, we therefore decided to investigate the state of activity of the branched-chain amino acid dehydrogenase complex in Friedreich's Ataxia. For these studies we utilized valine as the experimental substrate, thus the activity measured was that of valine dehydrogenase (VDH).

\section{SUBECTS AND METHODS}

Fourteen patients with typical Friedreich's Ataxia according to the criteria of Geoffroy et al, (1976), were selected for these studies. There were 8 women and 6 men, average age 26.4 years. Normal control volunteers were also studied, matched for sex and age. Thus a total of 14 control subjects ( 8 women and 6 men, age 25.8 years) were investigated. Informed consent was obtained from each subject.

Valine dehydrogenase activity in leukocytes was measured by the method of Dancis et al, (1963) using Valine $\left(-1-{ }^{14} \mathrm{C}\right)$ from New England Nuclear at specific activity of 53.9 $\mathrm{mCi} / \mathrm{m}$-mole as substrate and cold $\mathrm{L}$ Valine $(0.0585 \mathrm{~g} / 5 \mathrm{ml}$ sodium phosphate buffer). Beef liver catalase was from Beoringher-Manheim (250 $\mathrm{mg} / 2.5 \mathrm{ml}$, diluted $1 / 10$ with sodium phosphate buffer). Enzymatic activity is expressed in $\mathrm{p}$ moles/million WBC.

\section{RESULTS AND DISCUSSION}

The results of this experiment indicate that the Friedreich's patients, as a group, have decreased valine 
dehydrogenase (VDH) activity in leukocytes when compared to normal control subjects: $16.5 \pm 1.3$ versus $22.4 \pm 4.1 \mathrm{p}$ mole/million WBC, respectively. These results are illustrated in Fig. 1.

Three points must be made about these data: first, men and women did not differ (22.6 vs 21.7 mean values for controls; 16.6 vs 16.5 in Friedreich); secondly, the values obtained for an individual subject remained remarkedly constant from day to day, independent of diet. In one control subject done on 5 occasions the variation remained below $10 \%$ of total activity. Thirdly, it is evident that the decrease in activity in patients with Friedreich's Ataxia does not exceed $40 \%$ and that there is a considerable overlap between the two groups, even if the difference is statistically significant.

The degradation of the branchedchain amino acids leucine, isoleucine, and valine proceeds by deamination to an $\alpha$-keto acid and then by oxidative decarboxylation to a fatty acid. In the case of valine the steps are valine $\longrightarrow \alpha$-keto isovaleric acid $\longrightarrow$ isobutyric acid (Fig. 2). Loads of valine are known to result in increased serum concentrations of corresponding $\alpha$-keto isovaleric acid in healthy adults (Sternowsky et al, 1973). The oxidative decarbylation of the $\alpha$-keto acids of leucine, isoleucine and valine is carried out by a multienzyme complex called branched chain $\alpha$-keto dehydrogenase (BCDH) which is very similar, but not identical to the Pyruvate dehydrogenase complex (PDH). There is still a controversy on whether the same enzyme decarboxylates the three branched chain keto acids, but most authors would agree that $\alpha$ ketoisocaproic acid (from leucine) is not decarboxylated by exactly the same enzyme as $\alpha$-ketoisovaleric acid (from valine) (see Connelly et al, 1968;
Bowden and Connelly, 1968); $\alpha$ keto- $\beta$-methyl valeric acid appears to follow the pathway of leucine. The two postulated enzymes received the numbers EC 1.2.4.3 and EC 1.1.4.4. The enzyme was identified as a component of the mitochondrial inner membrane in human fibroblast and liver from human, rat and bovine (Johnson and Connelly, 1972). Removal from this membrane environment led to rapid loss of catalytic activity. It was also of relatively low activity when compared to pyruvate dehydrogenase and $\alpha$-ketoglutarate dehydrogenase, suggesting that it was present in low concentration.

The preliminary reports which led to the postulate of two enzymes were unfortunately based on partial purification of the enzyme (Rüdiger et al, 1972). The purification as a stable complex was only achieved recently in liver and kidney. (Danner et al, 1979; Pettit et al, 1978; Kean and Morrison,

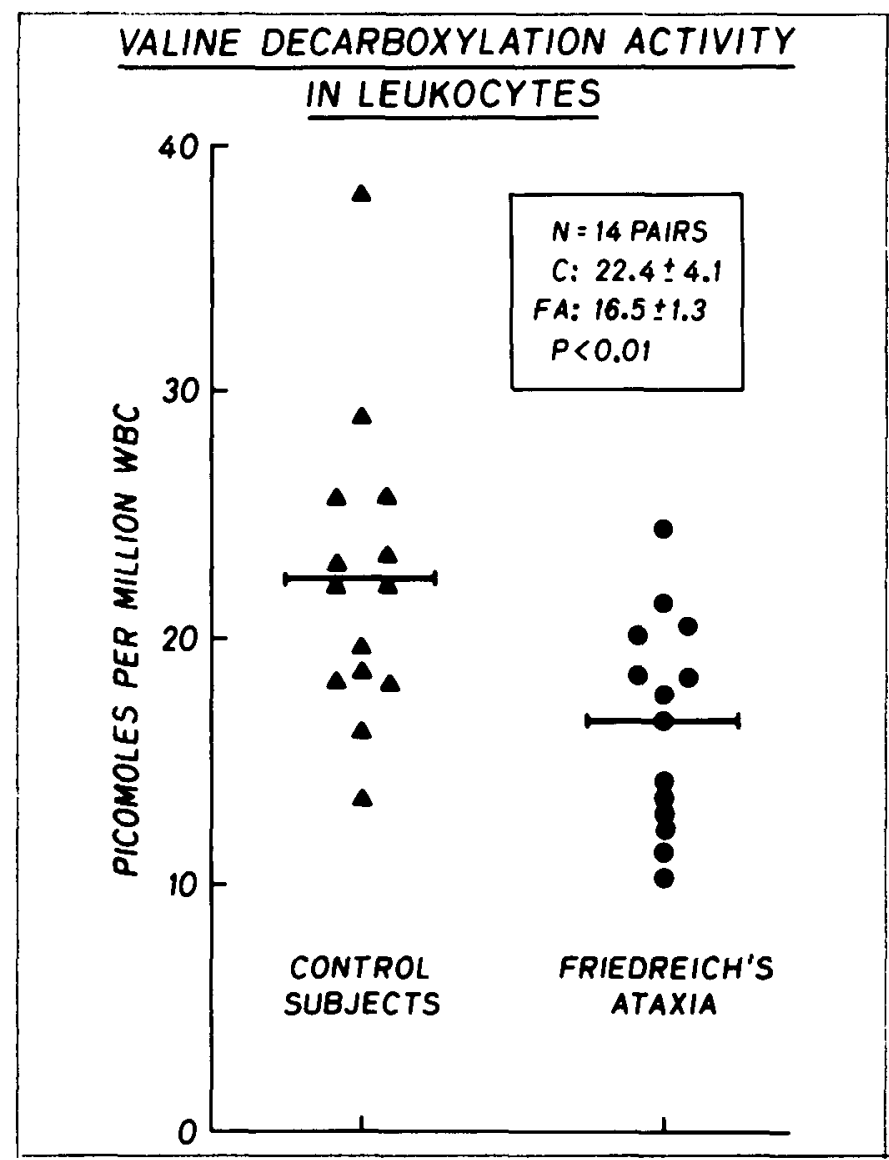

Figure $l$ - Distribution of Valine dehydrogenase (VDH) activity in control patients and in Friedreich's Ataxia.

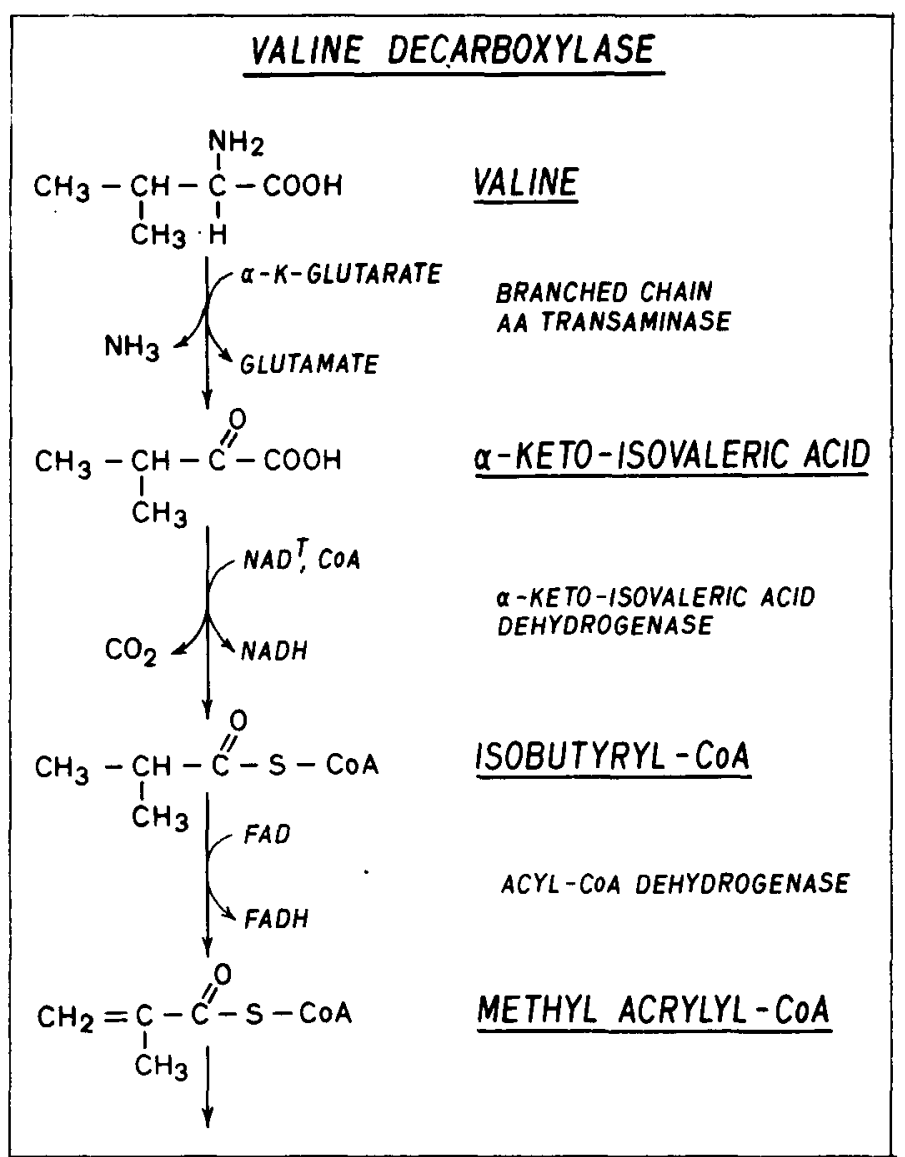

Figure 2 - Metabolic pathway for the oxidative decarboxylation of Valine. 
1979). The enzyme is anologous to the pyruvate dehydrogenase complex in that it is composed of a transacylase core, an $\alpha$-keto acid dehydrogenase and a dihydrolipoyl dehydrogenase, all non covalently associated in a multienzyme complex. There is competition among the branched chain $\alpha$-keto acids, probably at the level of the enzyme complex. Co-infusion of fatty acids (particularly octanoate) or ketone bodies resulted in substantial inhibition of metabolic flux through the enzyme complex (Bufffington et al, 1979). Regulation by insulin of this enzyme also takes place (Frick and Goodman, 1980). Similarly it was shown that valine decarboxylation was significantly increased and leucine decarboxylation significantly decreased in liver slices following hypophysectomy (Sullivan et al, 1979).

A defect in the transamination of valine was first identified in a young Japanese infant (Dancis et al, 1967). In that infant the administration of valine by mouth produced a prolonged elevation of plasma valine as compared to normal subjects, without concomitant increase in $\alpha$-keto acids. In "classic" Maple Syrup Urine disease, on the other hand, the defect is situated mainly in the decarboxylase component of branched-chain keto acid dehydrogenase (EC 1.2.4.1) (Rüdiger et al, 1972). This defect is manifested by different levels of activity of the enzyme in the classic type and numerous variants (Dancis et al, 1965; Dancis et al, 1972). There is even one form of the disease which can be corrected by high doses of thiamine (Scriver et al, 1971). Depending on the variant, the blood levels of valine, leucine or isoleucine will be higher than normal, but the greatest increase is in the blood and urine concentration of $\alpha$-keto acids.

These keto acids can be responsible for many other metabolic disturbances. Most symptoms of the disease may be explained by the observation of Snyderman et al, (1964) that of the three branched chain amino-acids, only leucine or its metabolites produce neurological changes. Similarly Tashian (1961) showed that elevation of alpha keto isocaproic acid (KICAP) was accompanied by inhibition of $\gamma$ -

Table 1

\title{
Inhibition of Pyruvate dehydrogenase activity
}

\author{
by alpha-keto acids
}

\section{Concentrations}

$\begin{array}{lll} & \text { KIVA } & \text { KICAP } \\ 0.01 M & 25.3 & 58.0 \\ 0.05 M & 53.1 & 73.8 \\ 0.5 M & 79.7 & 82.4\end{array}$

aminobutyric acid (GABA) synthesis. In 1961, Patrick has reported a general impairment in the utilization of pyruvic and $\alpha$-keto glutaric acids in a patient who died from branched chain ketoaciduria. Many other authors confirmed these findings and showed that KICAP inhibits pyruvic and $\alpha$ keto glutaric acid decarboxylation in rat liver slices (Bowden et al, 1971). In recent studies we (Cloutier and Barbeau, unpublished, 1982) confirmed this effect with KICAP and alpha keto valeric acid (KIVA), but to a lower degree with the latter compound. (Table 1).

In Friedreich's Ataxia, it is obvious that the transamination step is normal and that the slow-down in valine metabolism takes place at the level of the decarboxylation of $\alpha$-keto isovaleric acid (KIVA). It is also evident that this block is only partial, when present (one case had $80 \%$ inhibition, but the average range was from $15-40 \%$ inhibition) and moreover, that it does not characterize every patient with the disease. It is much less important than in Maple Syrup Urine Disease. A VDH deficiency is therefore not the primary genetic defect in Friedreich's Ataxia, even if its presence may result in accumulation of toxic metabolites which would explain the pathophysiology of some of the symptoms. Like the previously reported deficiencies in PDH/LAD, in $\alpha \mathrm{KGDH}$ and in GDH found in Friedreich's Ataxia, the VDH deficiency is probably a secondary event, reflection of a much more fundamental biochemical defect. The actual magnitude of the functional deficiency in branched-chain aminoacid metabolism, in vivo, could be demonstrated by load test with the precursor amino acids (see Barbeau et al, 1982, this issue).

\section{ACKNOWLEDGEMENTS}

The studies reported in this paper were supported by grants from l'Association Canadienne de l'Ataxie de Friedreich and the $O$. Malette Foundation of the Hottel-Dieu Hospital. The authors would like to thank Miss Danielle Bedard, R.N. for nursing assistance and Mrs. Hélène Lebrun-Crête for typing the manuscript.

\section{REFERENCES}

BARBEAU, A. (1980). Friedreich's Ataxia, 1980 - An overview of the physiopathology. Can. J. Neurol. Sci. 7: 455-468.

BARBEAU, A., BUTTERWORTH, R.F. NGO, T., BRETON, G., MELANCON, S., SHAPCOTT, D., GEOFFROY, G. and LEMIEUX, B. (1976). Pyruvate metabolism in Friedreich's Ataxia. Can. J. Neurol. Sci. 3: 379-397.

BLASS, J.P., KARK, R.A.P. and MENON, N.K. (1976). Low activities of the pyruvate and oxoglutarate dehydrogenase complexes in five patients with Friedreich's Ataxia. New Engl. J. Med. 295: 62-67.

BOWDEN, J.A. and CONNELLY, J.L. (1968). Branched chain $\alpha$-keto acid metabolism. Il. Evidence for the common identify of $\alpha$-keto 
isocaproic acid and $\alpha$-keto-methyl-valeric acid dehydrogenases. J. Biol. Chem. 243: 3526-3531.

BOWDEN, J.A., McARTHUR, C.L. and FRIED, M. (1971). The inhibition of pyruvate decarboxylation in rat brain by $\alpha$ ketoisocaproic acid. Biochem. Med. 5: 101-108.

BUFFINGTON, C.K., DE BUYSERE, M.S. and OLSON, M.S. (1979). Studies on the regulation of the branched chain $\alpha$-keto acid dehydrogenase in the perfused rat heart. J. Biol. Chem. 254: 10453-10458.

CONNELLY, J.I., DANNER, D.J. and BOWDEN, J.A. (1968). Branched chain $\alpha$ keto acid metabolism. I. Isolation, purification, and partial characterization of bovine liver $\alpha$-keto isocaproic: $\alpha$-ketomethyl-valeric acid dehydrogenase. J. Biol. Chem. 243: 1198-1203.

DANCIS, J., HUTZLER, J. and LEVITZ, M. (1963). The diagnosis of Maple Syrup Urine disease (branched chain keto aciduria) by in in vitro study of the peripheral leucocyte. Pediatrics 32: 234-238.

DANCIS, J., HUTZLER, J., LEVITZ, M. (1965). Detection of the heterozygote in Maple Syrup Urine Disease. J. of Pediat. 66: 595-603.

DANCIS, J., HUTZLER, J., SYNDERMAN, S.E. and COX, R.P. (1972). Enzyme activity in classical and variant forms of Maple Syrup Urine Disease. J. of Pediat. 81: 312-320.

DANCIS, J., HUTZLER, J., TADA, K., WADA, Y., MORIKAWA, T. and ARAKAWA, T. (1967). Hypervalinemia A defect in valine transamination. Pediatrics 39: 813-817.

DANNER, D.J., LEMMON, S.K., BESHARSE, J.C. and ELSAS, L.J. (1979). Purification and characterization of branched chain $\alpha$-keto acid dehydrogenase from bovine liver mitochondria. J. Biol. Chem. 254: 5522-5526.
FRICK, G.P. and GOODMAN, H.M. (1980). Insulin regulation of branched-chain $\alpha$-keto acid dehydrogenase in adipose tissue. J. Biol. Chem. 255: 6186-6192.

GEOFFROY, G., BARBEAU, A., BRETON, G., LEMIEUX, B., AUBE, M., LEGER, C. and BOUCHARD, J.P. (1976). Clinical description and Roentgenologic evaluation of patients with Friedreich's Ataxia. Can. J. Neurol. Sci. 3: 279-286.

JOHNSON, W.A. and CONNELLY, J.L. (1972). Cellular localization and characterization of bovine liver branched chain $\alpha$-keto acid dehydrogenase. Biochem. 11: 1967-1970.

KARK, R.A.P. and RODRIGUEZ-BUDELLI, M.M. (1979). Clinical correlations of partial deficiency of lipoamide dehydrogenase. Neurology 29: 1006-1013.

KEAN, E.A. and MORRISON, E.Y. STA. (1979). Isolation of a branched chain $\alpha$. keto-acid decarboxylase from rat liver. Biochem. Biophys. Acta 567: 12-17.

LIVINGSTONE, I.R., MASTAGLIA, F.L., and PENNINGTON, R.J.T. (1980). An investigation of pyruvate metabolism in patients with cerebellar and spino-cerebellar degeneration. J. Neurol. Sci. 48: 123-132.

MELANCON, S.B., POTIER, M., DALLAIRE, L., FONTAINE, G., GRENIER, B., LEMIEUX, B., GEOFFROY, G. and BARBEAU, A. (1978). Lipoamide dehydrogenase in Friedreich's Ataxia fibroblasts. Can. J. Neurol. Sci. 5: 115-118.

MENKES, J.H., HURST, P.L. and CRAIG, J.M. (1954). New syndrome: Progressive familial infantile cerebral dysfunction associated with an unusual urinary substance. Pediatrics 14: 462-468.

PATRICK, A.D. (1961). Maple Syrup Urine Disease. Archs. Dis. Childhood 36: 269 . 272.
PETTIT, F.H., YEAMAN, S.J. and REED, L.J. (1978). Purification and characterization of branched chain $\alpha$-keto acid dehydrogenase complex of bovine kidney. Proc. Natl. Acad. Sci. U.S.A. 75: 4881-4885.

RÜDIGER, H.W., LANGENBECK, U., SCHULZE-SCHENCKING, $M$. and GOEDDE, H.W. (1972). Defective decarboxylase in branched chain ketoacid oxidase multienzyme complex in classic type of Maple Syrup Urine Disease. Humangenetik 14: 257-263.

SCRIVER, C.R., MACKENZIE, S., CLOW, C.L. and DELVIN, E. (1971). Thiamineresponsive Maple Syrup Urine Disease. Lancet 1: 310-312.

SNYDERMAN, S.E., NORTON, P.M., ROITMAN, S. and HOLT, L.E. (1964). Maple Syrup Urine Disease, with particular reference to dietotherapy. Pediatrics 34: 454-472.

STERNOWSKY, H.J., ROBOZ, J., HUTTERER, F. and GAULL, G. (1973). Determination of $\alpha$-keto acids as silylated oxines in urine and serum by combined gas chromatography-mass spectrometry. Clin. Chim. Acta 47: 371-379.

SULLIVAN, S.G., POTTER, D.A., KRAUSS, M.R., DANCIS, J. and COX, R.P. (1979). Differential alterations in branched chain amino-acid decarboxylation in liver of hypophysectomized rats. Experientia 35: 1043-1044.

TASHIAN, R.E. (1961). Inhibition of brain glutamic acid decarboxylase by phenylalanine, valine and leucine derivatives: a suggestion concerning the etiology of the neurological defect in Phenylketonuria and branched chain ketonuria. Metabolism 10: 393-402.

WESTALL, R.G., DANCIS, J. and MILLER, S. (1957). Maple Sugar Urine Disease. Am. J. Dis. Child 94: 571-575. 